\title{
事例分析に基づく既存港湾施設の 改良設計の現状と課題
}

\author{
高野 向後 1 - 宮田 正史 1 - 藤井 敦 1 - 井山 繁1 ・ \\ 加藤 絵万 $2 \cdot$ 山路 徹 2 - 岩波 光保 3 ・横田 弘4 \\ 1 正会員 国土交通省 国土技術政策総合研究所（†239-0826 神奈川県横須賀市長瀬 3-1-1） \\ E-mail: takano-h92y2@mlit.go.jp, miyata-m92y2@mlit.go.jp \\ 2 正会員 海上・港湾・航空技術研究所 港湾空港技術研究所（干239-0826 神奈川県横須賀市長瀬 3-1-1） \\ 3 正会員 東京工業大学 環境・社会理工学院（干152-8552 東京都目黒区大岡山 2-12-1-M1-21） \\ 4 フェロー会員 北海道大学 大学院工学研究院 ( $\bar{T} 060-8628$ 北海道札幌市北区北 13 条西 8 丁目)
}

\begin{abstract}
近年，港湾では既存施設を対象とした改良事業が増加しているが，改良設計を進める上での技術的課題 とその解決方法を明確化したものはない。そこで，本研究では，全国の改良設計事例を収集し，改良の目 的や方法に着目し分析することにより，既存港湾施設の改良設計の現状と課題について取りまとめた．現 状については, 船舶大型化に対応した係留施設の増深など, 社会情勢の変化に応じた要請への早急な対応 が既存港湾施設の改良事業の特徵であることを明らかにした。また，改良設計上の課題は，長期の供用期 間中における設計法等の変更や，点検診断が困難なことによる既存部材の評価方法などであることを示し た，その上で，改良設計の枠組の構築に向けて，改良設計の基本事項と課題への対応の方向性を示した.
\end{abstract}

Key Words : existing port facility, reformation, protective facility for harbor, mooring facility, reformation design, case analysis

\section{1. はじめに}

既存の社会基盤の多くは高度経済成長期に集中的に 整備されており，今後急速に老朽化することが䀣念され ている. しかし，人口減少，少子高齢化などの社会情勢 の中, 社会基盤に充当できる財源は限られているため, 効果的な維持管理によって，これらを長期間に亘って利 用寸ることが求められている1).また，集中豪雨や巨大 地震などのたび重なる災害の発生から，大規模な災害対 策に向けた既存社会基盤の強化が求められている2).

社会基盤の一つである港湾施設においても，長期供用 およひ耐震強化・而津波強化が求められている．特に， 港湾施設は社会の経済成長を支える役割を果たすため, 社会情勢の変化に応じて, 港湾物流等の国際競争力の強 化に向けた船舶および荷役機械の大型化への早急な対応 が求められる.この場合, 新しい施設を整備するのでは なく, 現状利用している既存施設を最大限活用し，その 物理的な耐用年数に至る前に，大規模な改良を施して， それらの要請に対応することが多い，例えば，港湾の主 要な施設である岸壁では，より大型の船舶が速やかに利 用できるようにするため, 既存岸壁を補強しつつ前面水
域を増深するなどの改良が行われる，港湾施設の維持管 理や改良事業の特徵は，以上に示したように，今後の港 湾の発展や効率的な利用に向けた既存施設の有効活用に より, 港湾の再編や機能強化が継続的に求められること にある.

一方で，既存施設の改良においては，既存施設の置か れる状況や制約条件により，新規施設の設計とは異なる 技術的課題が生じることが多い3). しかし，港湾施設の 改良事業の現状を包括的に取りまとめ, 改良設計を進め る上での技術的課題とその解決方法を明確化したものは ない.

そこで，本研究では，その端緒として，全国の改良設 計事例を収集し，分析することにより，既存港湾施設の 改良設計の現状と課題を包括的に把握することを目的と した. 具体的には, 外郭施設および係留施設を対象とし た多数の改良設計事例から, 構造形式や経過年数, 改良 の目的や内容, および改良設計上の課題を整理・分析す る. その上で，既存施設の有効活用に資する改良設計の 枠組の構築に向けて, 改良設計を行う上での基本事項と 課題への対応の方向性を提示寸ることを目的とした. 


\section{2. 改良設計の現状の整理}

\section{(1) 改良設計の定義および事例収集}

本研究では，改良は「用途変更や設計条件等の変更に より，既存施設の一部または全部を利用し，既存施設に 対する要請（改良目的）に対応する行為」と定義する. なお，供用期間の延長も既存施設に対する要請の一つで あるため，改良に当てはまる，また，改良設計は改良の ための設計と定義する. 表-1 に改良設計に加え，新規設 計および補修設計の定義を整理する.

改良設計の現状の整理にあたっては，全国から平成 11 年度から平成 26 年度に実施された外郭施設 (防波堤およ び護岸）および係留施設（岸壁および物揚場）の設計事 例（908 件）を収集した。 そしてこの事例から，改良設 計の定義に基づき，改良設計事例 262 件 (外郭施設 : 130 件，係留施設：132 件）を抽出した.

\section{(2) 改良目的の分類}

改良設計事例を整理した結果，改良目的は表-2 に示す とおり，用途の変更，性能の変更，供用期間の延長の 3 つに分類することが可能であった.

「用途の変更」とは，防波堤から護岸への変更など， 既存施設の設置目的や基本的な機能を変更することを目 的として改良する場合である.この場合，後述する「性 能の変更」も同時に行われることになる.

表-1＼cjkstart新規施設・改良設計・補修設計の定義

\begin{tabular}{|c|c|}
\hline 殳計の区分 & 定義 \\
\hline 新規設計 & 施設を新たに設置する際に行う設計. \\
\hline 改良設計 & $\begin{array}{l}\text { 既存施設の改良を目的に行う設計. } \\
\text { ここで, 改良は用途変更や設計条件等の変更 } \\
\text { により，既存施設の一部または全部を利用し, } \\
\text { 既存施設に対する要請(改良目的)に対応する行 } \\
\text { 為である. 供用期間の延長も既存施設に対する } \\
\text { 要請の一つであり，改良に当てはまる. }\end{array}$ \\
\hline $\begin{array}{l}\text { 【部材の】 } \\
\text { 補修設計 }\end{array}$ & $\begin{array}{l}\text { 既存施設の維持を目的に行う構造部材等の補 } \\
\text { 修・補強に関する設計. } \\
\text { ここで, 維持は既存施設に対して点検診断を } \\
\text { 行い, 設計供用期間に亘って, 施設の機能また } \\
\text { は性能, あるいは車者を適切に維持する行為で } \\
\text { ある. 維持には, 施設を構成する構造部材等の } \\
\text { 劣化や損傷等による施設の機能の袈失または性 } \\
\text { 能の低下へ対応として, 構造部材等への補 } \\
\text { 修·補強を施すことや, 施設の点検, 清掃など } \\
\text { の管理や簡易な補修工事も含まれる. }\end{array}$ \\
\hline
\end{tabular}

「性能の変更」とは，要求性能のレベルを変更するこ とを目的として改良する場合，または要求性能そのもの を変更することを目的として改良する場合である．前者 の事例としては，防波堤における設計波高の増加によっ て，変動波浪に対する要求性能である「使用性」のレベ ルを向上させる場合などが該当する．後者の事例として は，通常の岸壁（レベル 1 地震動対応）を耐震強化岸壁 へと改良する際，レベル 1 地震動に対する「使用性」に 加えて，新たな要求性能としてレベル 2 地震動に対する 「修復性」を追加する場合などが該当する.

「供用期間の延長」とは，「用途の変更」や「性能の 変更」は必要とされないが，施設を当初の設計供用期間 を超えて継続利用したい際に，新たな設計供用期間を設 定し，供用期間を延長する場合である。

この3つの分類の内, 外郭施設と係留施設に共通して, 改良目的が「性能の変更」である事例が多かった(76\%).

「性能の変更」の事例の内，防波堤および護岸では波浪 防護のために嵩上げした事例，岸壁では而震化や船舶・ 荷役機械大型化への対応が行われた事例，物揚場では利 便性への対応として天端高の変更や施設前面に浮体の設 置が行われた事例が多かった。

\section{(3) 改良設計における設計供用期間}

改良設計事例で見られた設計供用期間の概念を図-1 に示す. 新規設計では, 設計供用期間は一般に 50 年とす

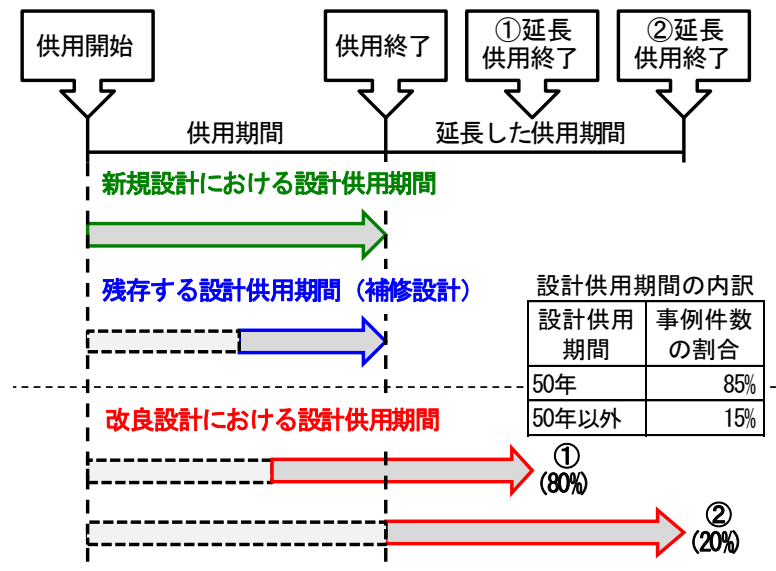

図-1＼cjkstart設計供用期間の概念図

表-2 改良目的の分類および内容

\begin{tabular}{|c|c|c|c|c|c|}
\hline 改良目的 & 説明 & 内容等 & 事例数 & 割合 & 具体例 \\
\hline 用途の変更 & $\begin{array}{l}\text { 既存施設の目的・用途（機能）を変 } \\
\text { 更させる場合. }\end{array}$ & 設置目的·用途の変更 & 16件 & $6 \%$ & $\begin{array}{l}\text { ·防波堤から護岸への変更 } \\
\cdot \text { 護岸から岸壁等への変更 } \\
\cdot \text { 岸壁等から護岸への変更 }\end{array}$ \\
\hline \multirow{6}{*}{ 性能の変更 } & \multirow{6}{*}{$\begin{array}{l}\text { 既存施設の目的・用途（機能）にー } \\
\text { 切の変更がないが, 要求性能を変更 } \\
\text { し, 性能や能力を変更（向上または } \\
\text { 低下） させる場合. }\end{array}$} & 設計波高等の見直し & 77件 & \multirow{6}{*}{$76 \%$} & ・防波堤または護岸の嵩上げ \\
\hline & & 設計津波高の見直し & 24件 & & ·防波堤または護岸の耐津波化 \\
\hline & & 設計地震動の見直し & 34 件 & & ·岸壁等の耐震化 \\
\hline & & $\begin{array}{l}\text { 荷役形態等の変更（対象船 } \\
\text { 舶・荷役機械等の変更） }\end{array}$ & 20 件 & & $\begin{array}{l}\text { 岸壁等の増深・減深 } \\
\cdot \text { 荷役機械の大型化への対応 }\end{array}$ \\
\hline & & 利便性への対応 & 38 件 & & $\begin{array}{l}\cdot \text { 岸壁等の天端高の変更 } \\
\text { ・船揚場の斜路長さの変更 }\end{array}$ \\
\hline & & その他 & 5 件 & & ·護岸の耐震性の向上 \\
\hline $\begin{array}{c}\text { 供用期間 } \\
\text { の延長 }\end{array}$ & $\begin{array}{l}\text { 設計供用期間の終了を迎える施設に } \\
\text { 対して，供用期間を延長する場合. } \\
\text { 設計供用期間の途中の変更も含む. }\end{array}$ & 新たな設計供用期間の設定 & 48件 & $18 \%$ & $\begin{array}{l}\text { ·防食エの取替え } \\
\cdot \text { 栈橋上部工の取替え }\end{array}$ \\
\hline
\end{tabular}


ることが多く，改良設計事例においても設計供用期間を 50 年に設定した事例(85\%)が多い. 設計供用期間を 50 年 以外に設定した事例の多くは，小型船舶が利用寸る水深 が浅い物揚場などであり,設計供用期間は 30 年であった。 また，改良設計の時期に関しては，当初の設計供用期間 の途中で新たに設計供用期間を設定した場合（図中(1)： 80\%）と，当初の設計供用期間の終了段階で再度設計供 用期間を設定した場合（図中(2)：20\%）に分類された。

\section{(4) 経過年数}

図-2に改良設計時点の経過年数の頻度分布を示す. 改 良設計時点の経過年数は平均で 37 年であり, 設計供用期 間の終了を迎えつつある経過年数 40-49 年の事例が最も 多かった (44 件).

一方で，経過年数が短い 20 年未満の事例（1-9 年 : 6 件，10-19年： 24 件，計 30 件）も比較的多かった. これ らの事例の多くは船舶・荷役機械大型化一の対応 (11 件), 而震化（3 件）・而津波化（3 件）の防災・減災に向けた 対応，波浪防護への対応（7 件）などであった. 特に, 係留施設では, 外郭施設と比較して, 経過年数が 20 年未 満の事例が多かった。これらは，船舶や荷役機械の大型 化など，社会情勢の変化に応じた要請への早急な対応の ためであり，このことが港湾施設の改良の特徵であるこ とを示すものである.

\section{(5) 係留施設の計画水深の変化量}

船舶大型化一の対応等の事例として，図-3 に係留施設 の計画水深の変化量を示寸. 当初の計画水深の大小に拘 わらず, 1〜3m を増深する設計事例 (27 件) が多かった. その一方で，船舶利用の実態に合わせて，水深を小さく して効率的な利用を図った事例（3 件）があったことも 注目すべき点である.

また，矢板式係船岸や栈橋の事例では，改良に伴う安 定性の不足や変状によって，鋼矢板や鋼管杭を撤去また は残置し，既設前面に新たに鋼矢板等を設置する事例が 多かった．重力式係船岸では，既設の本体工の設置水深 が改良後の計画水深程度であることを利用し，最小限の 床掘により増深を可能とした事例が多かった。このよう に，既存施設の利用を前提とする改良では，既存施設の 実態が改良断面の決定に大きく影響を与える.

\section{(6)＼cjkstart外郭施設の天端高の嵩上げ量}

而津波化，波浪防護への対応等の事例として，図-4に 外郭施設の天端高の嵩上げ量を示寸，防波堤，護岸とも に，嵩上げ量別の件数の割合に大きな差がない，比較的 大きな $4 \mathrm{~m}$ 以上の嵩上げが行われた事例があるが，これ らの事例には而津波化への対応だけでなく，越波防止一 の対応の事例も含まれていた.

\section{3. 改良設計における課題の整理}

\section{(1) 改良設計事例の分析}

改良設計における共通課題の整理にあたり，改良設計 事例を分析した. 図-5(a)に経過年数約 30 年の重力式防 波堤に対して，設計波浪の見直し（越波抑制）による性 能の変更を目的として改良する場合の課題の一例を示寸 本施設は, 改良設計にあたり事前に点検診断が実施され, 施設の沈下が確認されたものの，上部工，本体ケーソン 等に大きな劣化・損傷がないことが確認された．その結 果から，上部工，ケーソン等の利用が可能であると判断 され，上部工および消波工の嵩上げが行われた。

一方，この施設では見られなかったものの，次のよう な設計上の課題が発生することも想定される．波浪の見 直しや上部工嵩上げによって，全体の安定性やケーソン 底版（RC 部材）の耐力は確保されるものの，建設当初

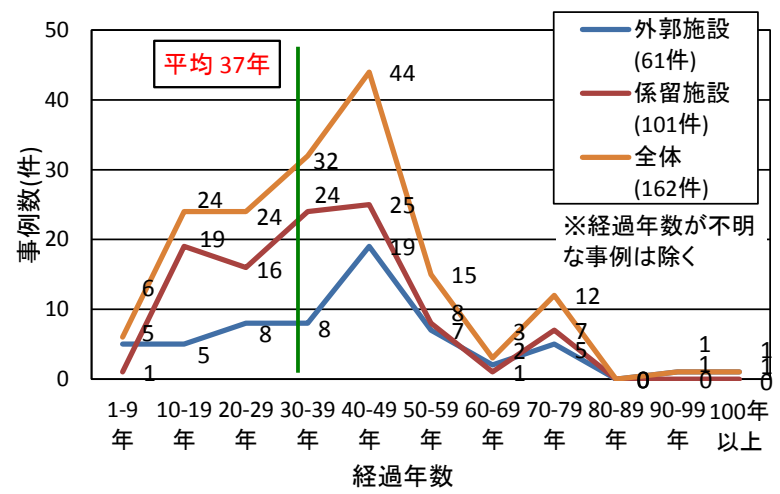

図-2 経過年数

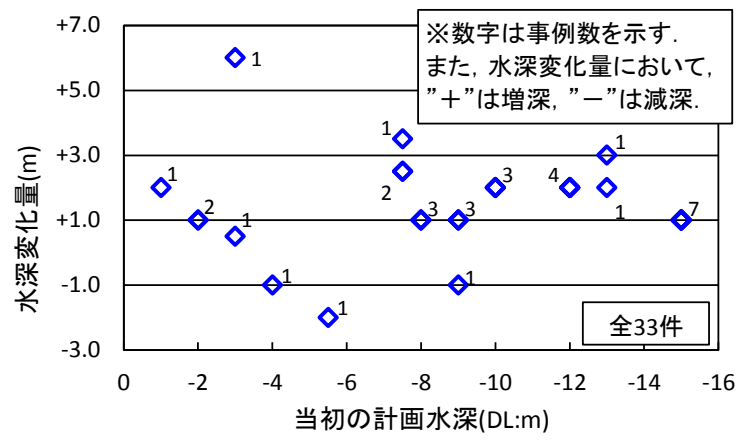

図-3 計画水深の変化量

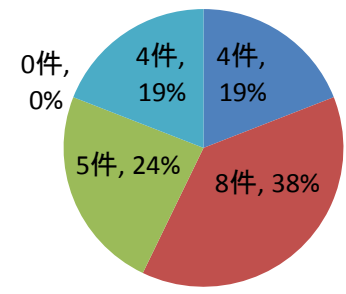

(a) 防波堤 21件

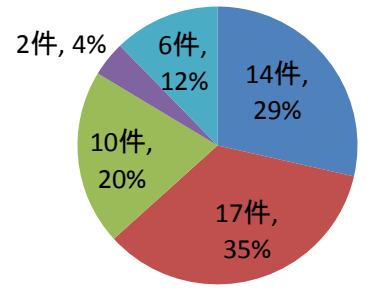

(b) 護岸 49件 1m未満

口 $3 \mathrm{~m}$ 以上 $4 \mathrm{~m}$ 未満 $\quad 4 \mathrm{~m}$ 以上

図-4 天端高の嵩上げ量 
から RC 部材の設計法が変更となり，建設当初では考慮 していない RC 部材の曲げひび割れ幅に対する照査にお いて, 許容值を僅かに満足しないことである.この場合， 改良時点の設計法で規定されている許容值を満足させる ためには，ケーソン内の中詰砂を取り出した後，底版上 へのコンクリートの充填を行うなど，大規模な断面補強 が必要となる。このように，新規施設の設計と同様の方 法で照査を行うと，既存施設を有効活用できる可能性が あるのにも拘わらず，大規模な断面補強が必要となるこ とは，合理性を欠く改良と考えられる.

同様に，図-5(b)には経過年数 50 年を迎える矢板式係 船岸に対して,今後 50 年間の供用期間の延長を目的とし て改良する場合の課題の一例を示す. 本施設は，建設当 初，矢板壁本体 (鋼部材) には防食が施されておらず, 腐食代による対応（設計供用期間中の腐食量を予め考慮 した設計）がされていたが，供用期間途中で電気防食を 施したことにより，矢板の耐力には十分な余裕があるこ とがわかった，そこで，電気防食（陽極）の取替えおよ び被覆防食が施されて，改良が行われた。

一方，実際には，設計で考慮することが困難な変状が 発生していることも考えられる．例えば，中規模地震の 作用により鋼矢板に残留応力が発生している可能性があ る.また，矢板を支えるタイ材（鋼部材）の全数につい て，腐食状況や変状の発生の有無を確認寸ることは困難 であり, 改良設計時に今後 50 年間に亘る性能の確保の可 否を適切に判断することは難しい。 また，防波堤と同様

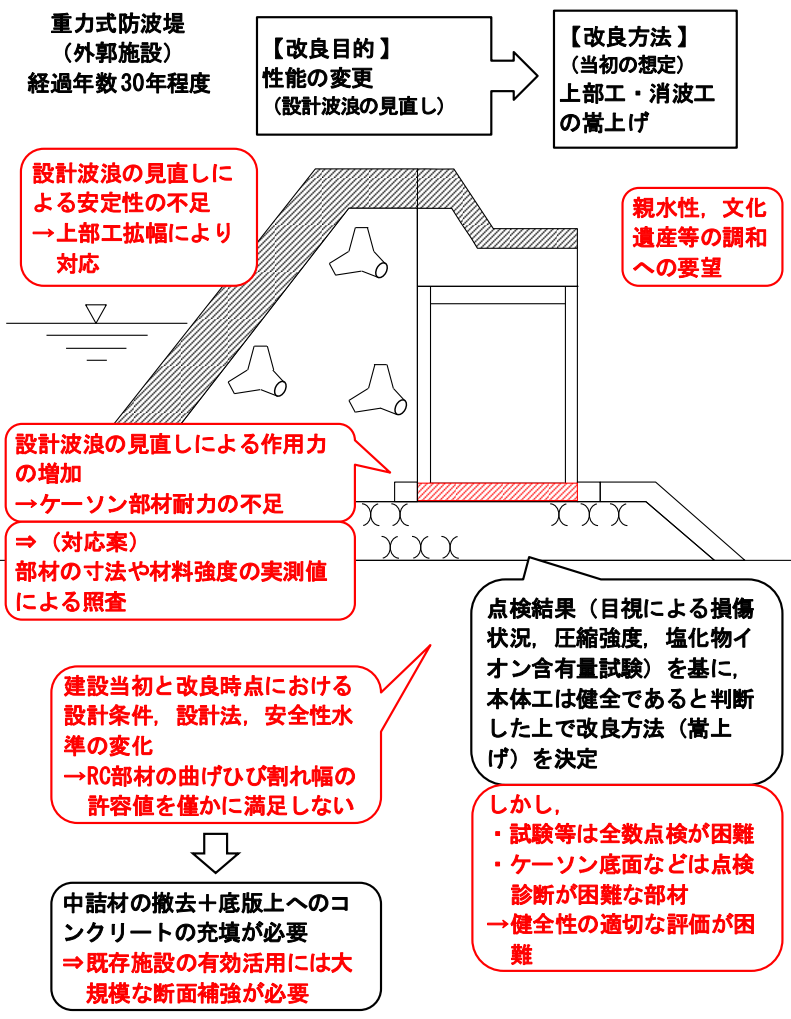

(a) 重力式防波堤
の課題も考えられる. すなわち，長期の供用期間におけ る設計条件，設計法，安全水準の変化により，改良時点 の設計法等を既存施設の改良設計に対して適用すると， そのまま既存施設を有効活用できるのにも拘わらず，大 規模な断面補強等の合理性を欠く可能性がある.

\section{(2) 改良設計における課題の整理}

全設計事例について，改良目的，改良方法および断面 決定の主要因を確認するとともに，(1)の分析例のように 設計上の課題を抽出した。 これを包括的に整理すると， 表-3に示す a)〜e)の 5 つに分類できる.

\section{a) 設計条件の設定}

波浪や地震動の自然条件，船舶や荷役の利用条件など, 改良設計時点で新たに設定した設計条件が当初の設計時 点よりも大きな作用を与え，既存施設の安全性等に影響 を及ぼし，大規模な改良が必要になる。また，これらの 作用に伴う残留応力による耐力の低下や，実測潮位や浸 水履歴を基にした設計条件が安全性等に影響を及ぼす。

一方で，地盤は圧密による強度増加が見込めることや， 既存部材の寸法や材料強度には実測值を用いることがで きる.これらの既存部材の実態に沿った設計条件を設定 することが耐力の上昇に寄与し，既存施設の有効活用に 繋がることが考えられる。

\section{b) 設計法等の変更}

性能設計の導入に伴い，それ以前の設計法 (仕様設計) とでは，同じ断面でも求められる安全水準等が異なるこ

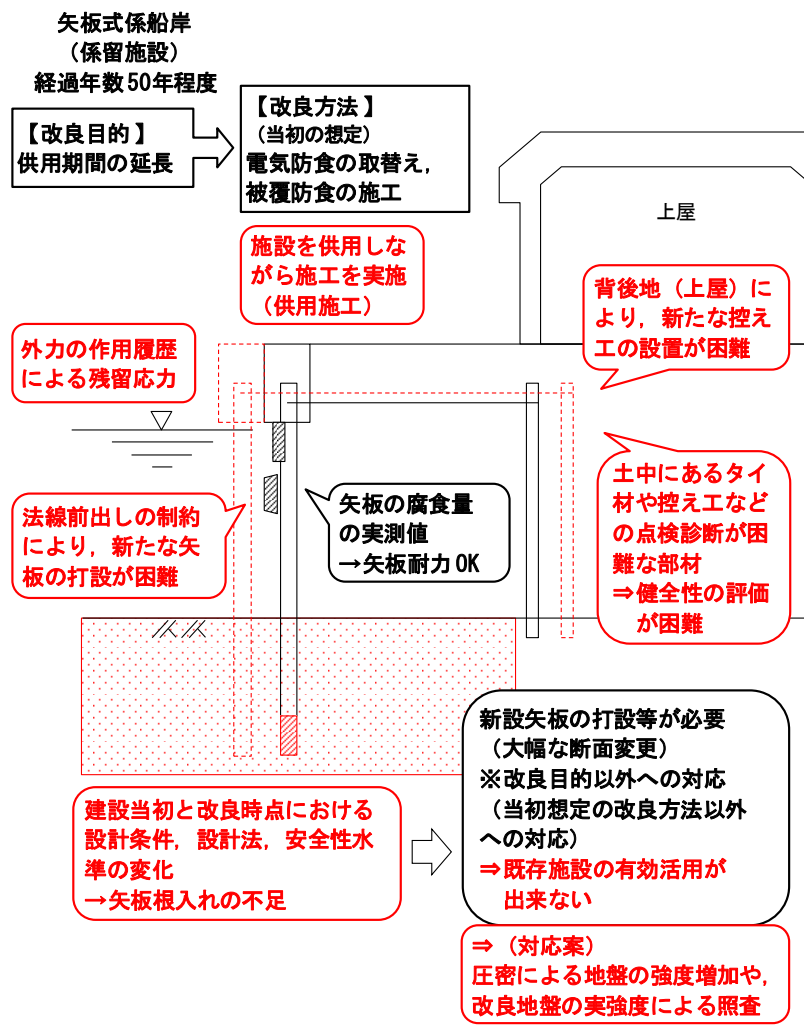

(b) 矢板式係船岸

図-5＼cjkstart課題の具体例 
とで，改良目的に応じた施設の改良以外に，新たな安全 水準への対応が必要となり, 大規模な改良が必要となる. 安全水準の他，港湾では水中の見かけの震度，動水圧の 考慮の有無，矢板の発生断面力の考え方などは，これま での研究によって算定方法が変更となっており，これら も施設の安全性の評価等に影響を及ぼす。

\section{c) 既存部材等の評価}

既存部材の変状の程度や保有耐力を評価した結果，既 存部材等の利用が不可であった場合や，大規模な補修・ 補強が必要であった場合は改良方法に大きく影響を与え る. その他，点検診断が困難または現実的には不可能で ある摩擦増大マットなどの既存部材の存在も含め，健全 性や残存耐力を定量的に評価ができないことも既存部材 等の評価に関する課題である。

\section{d) 当該施設の設置状況など}

施設の利用頻度が高く，施工期間中の供用休止が困難 であり，施設を供用しながらの施工（供用施工）や船舶 の接岸および荷役作業の際に隣接バースの利用（バース シフト）が必要となることが，施工方法や施工期間の制 約となり, 改良方法や施工方法に大きな影響を及ぼす。 また，既存荷役機械や背後地への影響や，親水性・文化 遺産等の調和への要望によって，改良方法または施工方 法の選定に影響を及ぼす。

\section{e） 法線前出しの可否（前出しの可能量）}

改良目的に伴い断面の変更や新しい部材の導入が必 要となった場合に，施設法線の制約によって工事範囲が 限定され，断面変更や新規部材の導入が困難となり，工 事費が高い工法を選択することになるなど，法線前出し の可否 (可能量) が改良方法に大きく影響を与える。ま た，埋立申請の必要性は制度面の課題であるが，法線前 出しに大きく関わる.

\section{表-3＼cjkstart改良設計における課題}

\begin{tabular}{|c|c|}
\hline \\
\hline \multicolumn{2}{|r|}{ 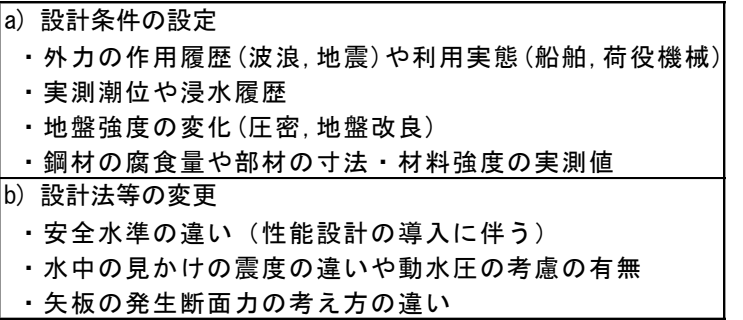 } \\
\hline & $\begin{array}{l}\text { 既存部材等の評価 } \\
\text { ·変状が確認された既存部材等への対応 } \\
\cdot \text { 改良目的によっては既存部材等の耐カ不足への対応 } \\
\text { ·定量的な評価が困難な既存部材等への対応 }\end{array}$ \\
\hline \multicolumn{2}{|r|}{$\begin{array}{l}\text { d当該施設の設置状況など } \\
\cdot \text { 供用施エの可否やバースシフトの可否 } \\
\text { - 既存荷役機械や背後地 (上屋, 民有地)への影響 } \\
\cdot \text { 親水性, 文化遺産等の調和への要望など }\end{array}$} \\
\hline \multicolumn{2}{|r|}{$\begin{array}{l}\text { e) 法線前出しの可否(前出しの可能量) } \\
\text { · 前出しの可否 } \\
\text { ·前出しの可能量 } \\
\text { ·埋立申請の必要性 } \\
\end{array}$} \\
\hline
\end{tabular}

\section{4. 課題への対応の方向性}

本章では，前章までの現状と課題を踏まえて，改良設 計における課題への対応について論ずる.まず，(1)にお いて，港湾施設の改良設計を行う上での重要な留意事項 を基本事項として提示寸る．その上で，(2)において，3. に示した課題への対応について，港湾施設を対象とした 現状の設計体系の範疇で対応できる方策を提示する.さ らに，(3)では，現状の設計体系の制約に捉われず，既存 施設の有効活用に向けた対応の方向性を論じる.

\section{(1) 改良設計の基本事項}

港湾施設は施設の新たな建設，改良に関わらず，国土 交通省令および告示である「港湾の施設の技術上の基準」 (技術基準) を遵守しなければならない。このため，改 良設計では新規設計と同様に，改良目的に応じた要求性 能を，新たに設定した設計供用期間に亘って満足するよ うに設計が行われるべきである.このことを勘案すると， 改良設計における性能照査は，改良時点の「港湾の施設 の技術上の基潐・同解説」4)に基づく標準的な設計法 (設 計条件の設定方法，性能照査に用いる手法と閾值など） を適用することが基本と考えられる．また，改良は既存 施設を利用寸ることが前提であるため，利用する既存部 材については, 劣化・損傷状況等の健全性や保有耐力の 定量的な評価を実施することが基本と考えられる。

\section{(2) 課題への対応}

改良設計では標準的な設計法を適用し，改良を達成さ せようとすると，各種の課題によっては合理性を欠く場 合がある。その一方で，改良設計では新規設計とは異な り，当該施設に関して様々な履歴情報や現況情報を得る ことができる，そのため，合理的な改良を行うには，ま ず，外力の作用履歴，利用実態，劣化・損傷状況，既存 部材の諸元や物性值など，既存施設に関する各種の情報 を最大限活用し，作用による応答值および構造物・部材 の耐力に基づく限界值を設定することが必要である。

また，性能照査においても，既存施設の状態をできる 限り精緻にモデル化した高度な数值解析や，現地試験に 基づく手法，その他，過去の実績や経験に基づく手法が 適用できる．これらの手法の適用にあたっては，取得で きる既存施設の情報を勘案すること ${ }^{5}$ が考えられる.

一方で，既存部材は点検診断が実施できない場合もあ り，その保有性能等の定量的な評価が困難であり，既存 部材の利用の判断が適切にできないことで，既存施設の 有効活用が困難な場合がある．特に，港湾施設では土中 部の部材が多いため, この問題は顕著である.このよう な場合は，類似構造・部材の過去の実績を踏まえて定性 的な評価に基づき，設計供用期間に亘る性能の確保が可 
能であるかを，補修・補強の必要性も含めて判断し，既 存部材を利用することが考えられる．また，これらの高 度な判断は有識者や専門技術者の関与の下で行うことも 一方策である。

\section{(3) さらなる対応への方向性}

上述した現行の設計体系における課題への対応では, 合理的な改良に向けた抜本的な解決策とはならない場合 もある，そこで，現行の設計体系に捉われずに対応する 場合の方向性について，一つの方策を以下に述べる.

現行の技術基準では，全施設に求められる要求性能と して使用性（レベル 1 地震動などの変動作用に対して損 傷しない状態に留める）が規定されている。しかし，施 設によっては供用期間中の地震動の見直しにより，設計 地震動が大きくなっている場合がある。このような場合 の改良設計では，改良時点のレベル 1 地震動に対して， 施設の要求性能を修復性（レベル 1 地震動の作用後に短 期間で修復できる程度の状態に留める)に改めることで, 既存施設を活用し, 継続的に利用することが考えられる. すなわち，既存施設の場合に限り，施設の重要度に応じ て要求性能の水準（性能グレード）を柔軟に設定するこ と ${ }^{6}$ が考えられる. なお，実際問題として，土木遺産と しての施設を維持していく場合などは，このような新し い枠組みが必要になると考えられる。

しかしながら，これらの対応を行った場合，当該施設 と周辺施設に安全水準の相違が生じ，比較的大きな作用 が発生した際に，一部の施設の倒壊が港湾全体としての 機能の袁失に繫がる恐れがある。そのため，上述した措 置については，既存施設の改良後の一定期間において暫 定的に認められるものとし，その間は維持管理における 点検診断等を強化することで対応し，将来的には新規施 設と同等の要求性能を満足するように再度改良を行うこ
とを規定するなど，港湾全体の持続性を考慮した上での 慎重な制度設計が必要となる。

\section{5. おわりに}

本研究では，全国の多数の改良設計事例に基づき，既 存港湾施設の改良設計の現状と課題を包括的に整理する ことで，改良設計を行う上での基本事項と課題への対応 の方向性が提示できた．既存施設を有効に利用した改良 を進めるには，現状の制度も含めて検討する余地がある と考えられ，今後も，より合理的な改良に向けた改良設 計の枠組について研究を進めたい.

\section{参考文献}

1) 国土交通省：今後の社会資本の維持管理・更新のあり 方について (答申) [http://www.mlit.go.jp/common/00102 3147.pdf] , 2013. 参照 2017-03-24.

2) 国土交通省 : 国土交通省南海卜ラフ巨大地震対策計画 平成 28 年度の実施状況【重点施策】 [http://www.mlit.go.jp/river/bousai/earthquake/pdf/earthqu ake/6kai-ref02-03.pdf] ， 2016. 参照 2017-03-24.

3) 高野向後，宮田正史，藤井敦，井山繁，加藤絵万，山 路徹，坂田憲治 : 既存の港湾施設の改良における設計 上の留意事項に関する検討〜外郭施設および係留施 設を対象として〜，国土技術政策総合研究所資料， No.944, pp.16-21, 2017.

4) 日本港湾協会 : 港湾の施設の技術上の基準 - 同解説, pp.41-78, 2007.

5) 日本コンクリート工学会 : 既存コンクリート構造物の 性能評価指針, pp.1-25, 2014.

6) 土木学会：土木構造物共通示方書 性能・作用編, pp.8-20, 2016.

(2017.2.2 受付)

\title{
CURRENT SITUATION AND PROSPECTS OF REFOMATION DESIGN FOR EXISTING PORT FACILITIES
}

\author{
Hisachika TAKANO, Masafumi MIYATA, Atsushi FUJII, Shigeru IYAMA, \\ Ema KATO, Toru YAMAJI, Mitsuyasu IWANAMI and Hiroshi YOKOTA
}

Reformation projects for existing protective and mooring facilities in harbors have recently shown rapid increase to meet new requirements due to changes in social and economic situations. Accordingly, it is required to setup a design framework that is not the same as those for a new construction, but there are no guidelines available how to execute facility reformation design.

In this paper, we collected 262 facility reformation projects nationwide in Japan and performed case analyses focusing on motivation and methods of reformation. As a result, we showed the current situations of existing port facility reformation that was urgently responded to the requests corresponding to the change in social situations. Also, we clarified typical problems during reformation design such as changes in verification methods from the originals and difficulty in structural performance evaluation of an existing structure. In addition, we showed the basic of the reformation design and the prospects to solve the problems for the reformation design of existing port facility. 